\title{
Impact of Facebook Addiction on Students Academic Performance
}

\author{
Nida Tabassum Khan ${ }^{1 *}$ and Sohail Ahmed ${ }^{2}$ \\ Department of Biotechnology, Balochistan University of Information Technology Engineering and Management Sciences, Pakistan
}

*Corresponding author: Nida Tabassum Khan, Department of Biotechnology, Faculty of Life Sciences and Informatics, Balochistan University of Information Technology Engineering and Management Sciences,(BUITEMS), Quetta, Pakistan, Tel: 03368164903;

Email: nidatabassumkhan@yahoo.com

Submission: 㘹 May 03, 2018; Published: 㘹 May 15, 2018

\begin{abstract}
Facebook is the most commonly used social networking site for people to communicate and interact with their peers on daily basis. Majority of facebook users comprised of teenagers and youngsters that are undergraduates. Although excessive use of facebook has its drastic implications especially affecting the academic performance of students. Nevertheless, within couple of years excessive use of facebook has been recognized as addiction and measures have been taken to minimize its excessive use. This study revealed that the incidence of facebook addiction among undergraduates was quiet high along with disturbing effects on student's academics resulting in lower GPAs.
\end{abstract}

Keywords: Addiction; GPA; Bergen scale

\section{Introduction}

Facebook was created to provide a networking medium for people especially students to interact with others [1]. But in today's scenario facebook is regarded as the primacy social-networking site [2]. It was reported that approximately $94 \%$ of undergraduate students were active facebook users spending countless hours on daily basis [3]. According to a recent report it was stated that approximately ten billion minutes per day was devoted to facebook by users [4]. And the average minute per user per day escalated by $57 \%$ [5]. Here the underlying concern is the prolonged time being spent on Facebook with negative impacts on students' academic accomplishments [6]. According to a study it was reported that students that devotes bigger number of hours on facebook tends to score low GPAs with poor overall performance [7]. Another study revealed that substantial facebook use is common among students with less demanding scholastic accomplishments [8]. The main aim of this survey was to determine the impact of facebook addiction on undergraduates' academic performance.

\section{Materials and Methods}

100 randomly selected undergraduate students at BUITEMS were examined. Keeping in mind all those participants has an active facebook account. Bergen scale was used for the assessment of facebook addiction with a score $>80$ as facebook addict [9]. Demographic data, academic scoring i.e. GPA and time spent on Facebook was also obtained from each participant. Microsoft excel was used for analysis of the raw data.

\section{Results}

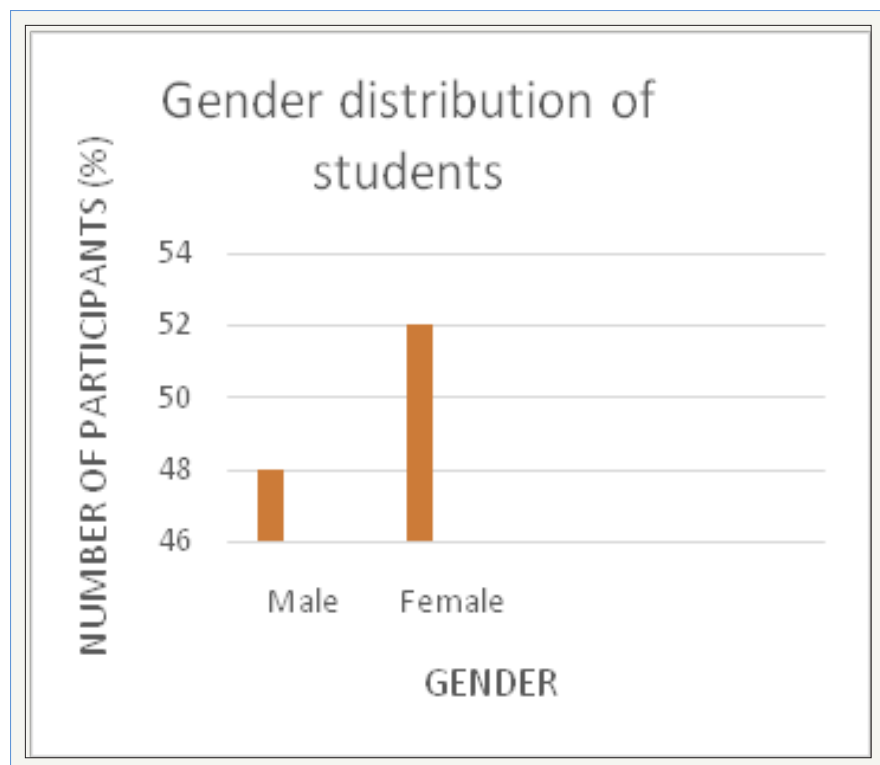

Graph 1: Gender distribution.

$52 \%$ were females and $48 \%$ were males out of a total of 100 selected participants as depicted in Graph 1.

Graph 2 represents the distribution of facebook addiction factors. 


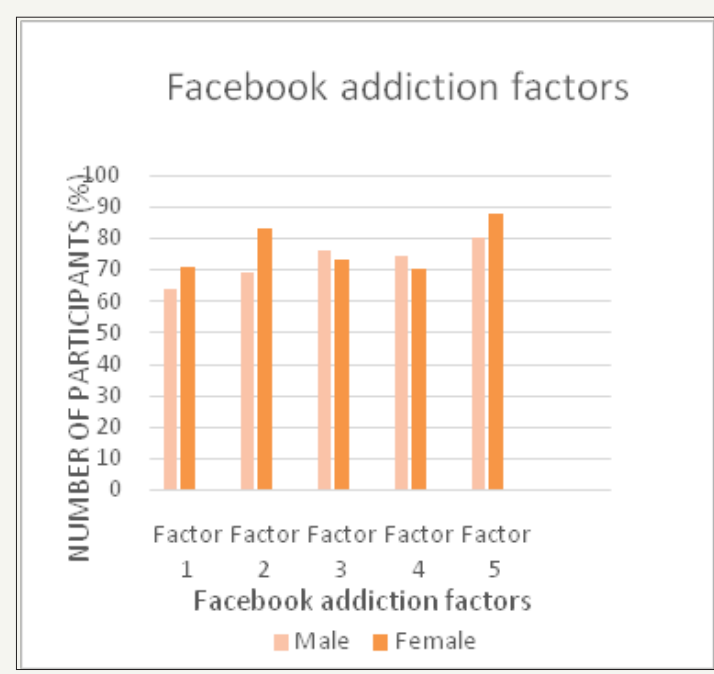

Graph 2: Prevalence of facebook addiction factors.

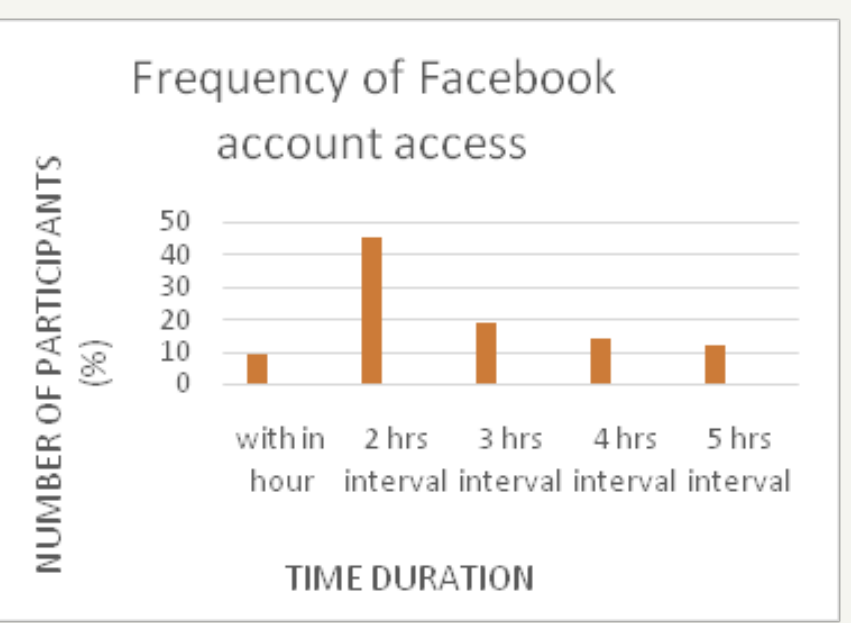

Graph 3: Frequency of Facebook account access Graph 4 reveals the current GPA of the selected participants.

Frequency of Facebook account access every day is given in Graph 3; (Graph 4).

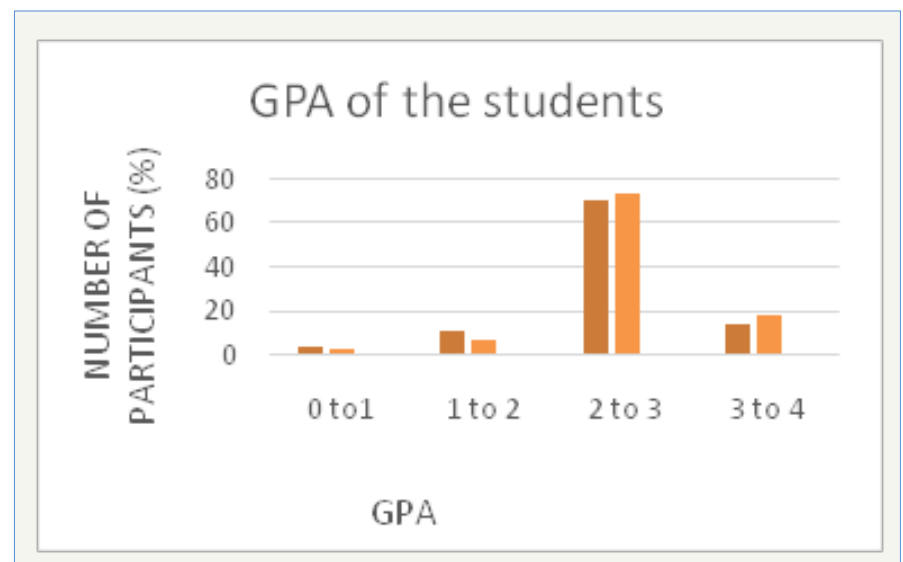

Graph 4: GPA of the students.

Incidence of facebook addiction is given in Graph 5

\section{Facebook Addiction level}

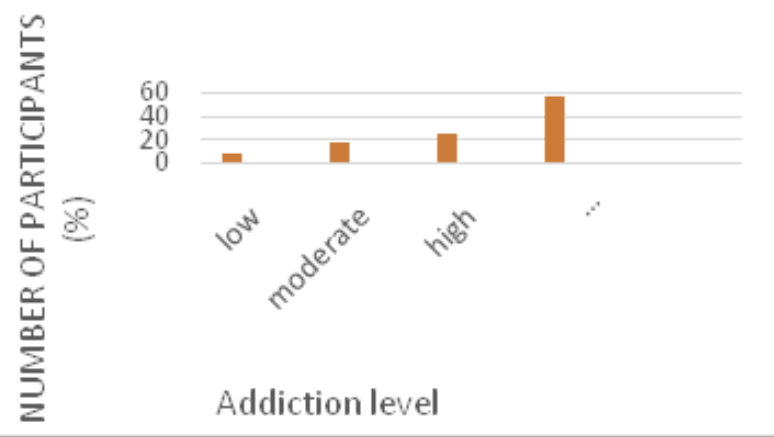

Graph 5: Level of facebook addiction.

\section{Discussion}

Our study revealed a strong relationship between facebook addiction and students GPA. As depicted in Graph 2 \& 4 that facebook usage is seen in students having lower GPA's. Since spending too much time fason facebook results in poor academic performance as depicted in Graph 3 [10]. Too much hours utilized on facebook causes disturbance in normal everyday routine and eventually leads to poor performance $[11,12]$. Obtained results also indicated that high prevalence of facebook addiction was seen in students that tend to be more social and consider facebook as an integral aspect of their life [13]. According to a study it was reported that the highest ratio of facebook users belongs to the adolescent and young undergraduates that uses facebook for gaming, emailing, instant messaging etc [14]. Besides these social network sites such as facebook, it provides an interactive platform for people for displaying their public/private profiles and using them for socializing with their peers [15]. However the far stretching acceptance of facebook has raised an emerging concern among people regarding its damaging implications on the lives of undergraduates [16]. With over 800 million facebook users, 350 million people can easily access facebook through their cell phones [17]. With the advent of technology, access to these sites is not a problem [18]. Creating online profiles for friends and peers is very popular among undergraduates for the portrayal of their fascinating life and is common among both the genders as indicated in Graph 5; [19]. With escalating number of individuals utilizing facebook for uploading private pictures, videos etc it could be exploited [20]. It was reported that preeminent use of Facebook develops addiction which was seen prominent in overenthusiastic undergraduates that tries to portray their personalities as tempting as they can [21]. Along with their desire for diversity, new encounters and inquisitiveness of the mind $[22,23]$. The provision of fresh ideas about connecting to people and opportunities for additional experiences may be why students spend long hours on Facebook [24]. However this might cause a diversion from their path to complete their academic goals set out for them leading to a downfall. Therefore it is important to recognize the excessive usage of facebook as addiction and steps 
should be taken to minimize or regulate its use among students so their studies are not affected.

\section{Conclusion}

Though facebook is an interactive platform for the students to share their life with their friends and peers but its excessive use has implications, not only on their academics but also on their personal life.

\section{References}

1. Ross C, Orr ES, Sisic M, Arseneault JM, Simmering MG, et al. (2009) Personality and motivations associated with facebook use. Computers in Human Behavior 25(2): 578-586.

2. Lampe C, Ellison NB, Steinfield C (2008) Changes in use and perception of facebook. In Proceedings of the 2008 ACM conference on Computer supported cooperative work ACM, pp. 721-730.

3. Junco R (2012) The relationship between frequency of facebook use, participation in facebook activities, and student engagement. Computers \& Education 58(1): 162-171

4. Valenzuela S, Park N, Kee KF (2009) Is there social capital in a social network site? Facebook use and college students' life satisfaction, trust, and participation. Journal of Computer-Mediated Communication 14(4): 875-901.

5. Kross E, Verduyn P, Demiralp E, Park J, Lee DS, et al. (2013) Facebook use predicts declines in subjective well-being in young adults. PloS One 8(8): e69841.

6. Junco R (2012) Too much face and not enough books: The relationship between multiple indices of Facebook use and academic performance. Computers in Human Behavior 28(1): 187-198.

7. Kittinger R, Correia CJ, Irons JG (2012) Relationship between facebook use and problematic Internet use among college students. Cyberpsychol Behav Soc Netw 15(6): 324-327.

8. Kirschner PA, Karpinski AC (2010) Facebook® and academic performance. Computers in Human Behavior 26(6): 1237-1245.

9. Andreassen CS, Torsheim T, Brunborg GS, Pallesen S (2012) Development of a facebook addiction scale. Psychol Rep 110(2): 501-517.

10. Kross E, Verduyn P, Demiralp E, Park J, Lee DS, et al. (2013) Facebook use predicts declines in subjective well-being in young adults. PloS one 8(8): e69841.
11. Rouis S, Limayem M, Salehi-Sangari E (2011) Impact of facebook usage on students' academic achievement: Role of self-regulation and trust. Electronic Journal of Research in Educational Psychology 9(3): 961-994.

12. Lloyd J, Dean LA, Cooper DL (2007) Students' technology use and its effects on peer relationships, academic involvement, and healthy lifestyles. NASPA Journal 44(3): 481-495

13. Pempek TA, Yermolayeva YA, Calvert SL (2009) College students' social networking experiences on Facebook. Journal of Applied Developmental Psychology 30(3): 227-238.

14. Ellison NB, Steinfield C, Lampe C (2007) The benefits of facebook "friends:" Social capital and college students' use of online social network sites. Journal of Computer-Mediated Communication 12(4): 1143-1168.

15. Gonzales AL, Hancock JT (2011) Mirror, mirror on my facebook wall: Effects of exposure to facebook on self-esteem. Cyberpsychol Behav Soc Netw 14(1-2): 79-83.

16. Hamade SN (2013) Perception and use of social networking sites among university students. Library Review 62(6/7): 388-397.

17. Kim JH, Kim MS, Nam Y (2010) An analysis of self-construals, motivations, facebook use, and user satisfaction. Intl Journal of Human-Computer Interaction 26(11-12): 1077-1099.

18. Amichai-Hamburger Y, Vinitzky G (2010) Social network use and personality. Computers in human behavior 26(6): 1289-1295.

19. Bicen H, Cavus N (2011) Social network sites usage habits of undergraduate students: Case study of facebook. Procedia-Social and Behavioral Sciences 28: 943-947.

20. Steel E, Fowler G (2010) Facebook in privacy breach. The Wall Street Journal 18: 21-22.

21. Farooqi H, Patel H, Aslam HM, Ansari IQ Khan M, Iqbal N, Nadeem A (2013) Effect of facebook on the life of medical university students. Int Arch of Med 6(1): 40.

22. Lee EB (2015) Too much information: Heavy smart phone and facebook utilization by African American young adults. Journal of Black Studies 46(1): 44-61.

23. Negussie N, Ketema G (2014) The relationship between Facebook practice and academic performance of university students. Asian Journal of Humanities and Social Sciences (AJHSS) 2(2): 1-7.

24. Mahmood S, Farooq U (2014) Facebook addiction: A study of big-five factors and academic performance amongst students of IUB. Global Journal of Management and Business Research 14(5): 54-71.
Creative Commons Attribution 4.0 International License

For possible submissions Click Here

\section{Submit Article}

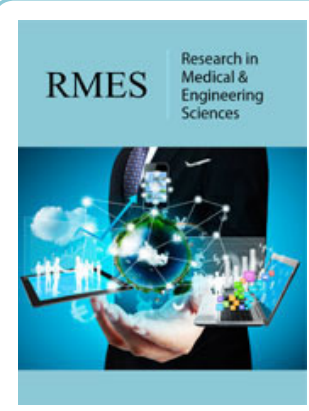

\section{Research in Medical \& Engineering Sciences}

\section{Benefits of Publishing with us}

- High-level peer review and editorial services

- Freely accessible online immediately upon publication

- Authors retain the copyright to their work

- Licensing it under a Creative Commons license

- Visibility through different online platforms 